\title{
Histone deacetylase inhibitor trichostatin A enhances the antitumor effect of the oncolytic adenovirus H101 on esophageal squamous cell carcinoma in vitro and in vivo
}

\author{
JUNFEN MA ${ }^{1}$, NAN LI $^{1}$, JIMIN ZHAO ${ }^{2}$, JING LU ${ }^{2}$, YANQIU MA ${ }^{3}$, \\ QINGHUA ZHU $^{1}$, ZIMING DONG $^{2}$, KANGDONG LIU $^{2 *}$ and LIANG MING ${ }^{1 *}$
}

${ }^{1}$ Department of Clinical Laboratory, The First Affiliated Hospital of Zhengzhou University, Zhengzhou, Henan 450052;
${ }^{2}$ Department of Pathophysiology, School of Basic Medical Sciences, Zhengzhou University, Zhengzhou, Henan 450001;
${ }^{3}$ Department of Obstetrics and Gynecology, Huaihe Hospital of Henan University, Kaifeng, Henan 475001, P.R. China

Received July 28, 2015; Accepted January 10, 2017

DOI: $10.3892 / \mathrm{ol} .2017 .6069$

\begin{abstract}
Replication-selective oncolytic virotherapy provides a novel modality to treat cancer by inducing cell death in tumor cells but not in normal cells. However, the utilization of oncolytic viruses as a stand-alone treatment is problematic due to their poor transduction efficiency in vivo. H101 was the first oncolytic adenovirus (Ads) to be approved by the Chinese FDA, and exhibits modest antitumor effects when applied as a single agent. The multiple histone deacetylase inhibitor trichostatin A (TSA) has been demonstrated to potently enhance the spread and replication of oncolytic Ads in several infection-resistant types of cancer. The present study aimed to investigate the antitumor effects of H101 in combination with TSA on esophageal squamous cell carcinoma (ESCC) in vitro and in vivo, and determine the mechanisms underlying these effects. H101 and TSA in combination increased the survival of mice harboring human ESCC cell line-tumor xenografts, as compared with mice treated with these agents individually. Therefore, TSA may enhance the antitumor effects of H101 in ESCC.
\end{abstract}

Correspondence to: Dr Kangdong Liu, Department of Pathophysiology, School of Basic Medical Sciences, Zhengzhou University, 100 Kexue Avenue, Zhengzhou, Henan 450001, P.R. China E-mail: kdliu@zzu.edu.cn

Dr Liang Ming, Department of Clinical Laboratory, The First Affiliated Hospital of Zhengzhou University, 1 Jianshe Road, Zhengzhou, Henan 450052, P.R. China

E-mail: mingliang@zzu.edu.cn

*Contributed equally

Key words: histone deacetylase inhibitor, trichostatin A, esophageal squamous cell carcinoma, oncolytic adenovirus

\section{Introduction}

Despite advances in the treatment of esophageal squamous cell carcinoma (ESCC), the overall mortality rate for this disease remains high (1). The frequency of late-stage diagnosis, high incidence of postsurgical local-regional recurrence and occurrence of distant metastasis contributes to this high mortality $(2,3)$. At present, the therapeutic strategies for ESCC include surgery, chemotherapy regimens and radiotherapy (4). These treatment methods are unable to eradicate all malignant cells, and are associated with frequent side effects (5-7). Therefore, numerous investigations have focused on developing alternative interventions, including tumor-specific replicating viruses (4).

The well-characterized modified adenovirus (Ads), H101 oncolytic Ads, varies from wild-type Ads in that the E1B55 $\mathrm{kDs}$ gene and the $\mathrm{E} 3$ region are deleted $(8,9)$. This approach is able to produce viral agents with the ability to selectively enter and replicate in tumor cells, consequently leading to cancer cell lysis with minimal damage to surrounding normal cells (10). It is hypothesized that the infecting oncolytic virus $(\mathrm{OV})$ may spread through a solid tumor and eliminate it through the release of progeny virions and activation of the antitumoral immune response (11-14). However, clinical trials in patients with head and neck cancer have revealed that the efficacy of this treatment is limited when it is utilized as a single modality, potentially due to inefficient intratumoral viral dispersal and the barriers imposed by the tumor microenvironment (15). Therefore, oncolytic Ads H101 requires combination with another modality to improve its antitumor activity $(9,14,16-18)$.

During transcription, histone acetylation/deacetylation is a major regulator of chromatin structural dynamics (19). Histone deacetylase inhibitors (HDACIs) block the activity of histone deacetylases, leading to the increased acetylation of histones and causing non-histone proteins to form a compact and transcriptionally repressed chromatin structure (20-22). HDACIs have been reported to inhibit the ability of tumor cells to mount a productive antiviral response (23-25). At present, trichostatin A (TSA) is considered the most promising HDCAI 
for tumor treatment, functioning as a potent inhibitor of cyclin D1 with the ability to arrest cell-cycle progression (26).

In the present study, the ability of TSA to augment the oncolytic activity of H101 was evaluated. The results suggested that the HDACI TSA potently and selectively enhanced the replication of H101 virions in ESCC in vitro and in vivo. Furthermore, the mechanism underlying TSA-mediated enhancement of the oncolytic activity of H101 was examined.

\section{Materials and methods}

Cell culture. The EC1 human esophageal carcinoma cell line was provided by The Department of Cell Biology, Hong Kong University (Hong Kong, China). This cell line has been demonstrated to be poorly-differentiated squamous cell carcinoma (27). EC1 cells were propagated in monolayer culture in RPMI-1640 medium (Gibco; Thermo Fisher Scientific, Inc., Waltham, MA, USA) supplemented with $10 \%$ inactivated fetal bovine serum $\left(56^{\circ} \mathrm{C}\right.$; $30 \mathrm{~min}$; Hyclone Laboratories, Logan, UT, USA), $1 \times 10^{5} \mathrm{U} / 1$ penicillin and $100 \mu \mathrm{g} / 1$ streptomycin in a humidified atmosphere with $5 \% \mathrm{CO}_{2}$ at $37^{\circ} \mathrm{C}$.

Reagents and treatments. TSA was purchased from Sigma-Aldrich (Merck Millipore, Darmstadt, Germany) and dissolved in dimethyl sulfoxide (DMSO) to produce a $5 \mathrm{mM}$ stock solution, which was stored at $-20^{\circ} \mathrm{C}$. Control cells were treated with DMSO in parallel during each experiment.

Cell viability assay. EC1 cell lines were seeded at a density of $5 \times 10^{5}$ cells/well in 96-well microtiter plates. The cells were incubated at $37^{\circ} \mathrm{C}$ with $5 \% \mathrm{CO}_{2}$ for $24 \mathrm{~h}$ and then were treated with TSA at various concentrations $(0.1,0.3$ and $0.5 \mu \mathrm{M}$; prepared from a stock solution dissolved in DMSO) for 24, 48 and $72 \mathrm{~h}$. Cells treated with identical concentrations of DMSO were used as controls. A total of $4 \mathrm{~h}$ prior to absorbance evaluation, $10 \mu \mathrm{l}$ Cell Counting Kit-8 (CCK-8; Dojindo Molecular Technologies, Inc., Kumamoto, Japan) solution was added to each well and incubated for $24 \mathrm{~h}$ at $37^{\circ} \mathrm{C}$. Absorbance was determined at a wavelength of $450 \mathrm{~nm}$ for each well using an enzyme-labeling instrument (Multiskan G0; Thermo Fisher Scientific, Inc.). All experiments were performed independently in triplicate.

Apoptosis assay. Following incubation with or without TSA at various concentrations $(0.1,0.3$ and $0.5 \mu \mathrm{M})$ for $48 \mathrm{~h}, \mathrm{EC} 1$ cells were harvested using $2.5 \mathrm{~g} / 1$ trypsin and washed twice with PBS. A total of $1 \times 10^{5}$ cells were stained with fluorescein isothiocyanate (FITC)-Annexin V/propidium iodide (PI) using an Annexin V-FITC kit (Beckman Coulter, Inc., Brea, CA, USA), according to the manufacturer's protocol. Subsequently, the apoptosis of $1.5 \times 10^{4}$ stained cells was quantified using flow cytometry (BD Biosciences, Franklin Lakes, NJ, USA). Each experiment was performed in triplicate. BD CellQuest ${ }^{\mathrm{TM}}$ software version 3.0 (BD Biosciences) was used to calculate the proportion of apoptotic cells. Negative staining for Annexin V and PI indicated viable cells; early apoptotic cells were positive for Annexin V and negative for PI, whereas late apoptotic cells were positive for Annexin V and PI.

In vitro $\mathrm{H} 101$ oncolytic Ads replication assay. $\mathrm{EC1}$ cells were cultured on 6 -well plates $\left(5 \times 10^{5}\right.$ cells/well) at $37^{\circ} \mathrm{C}$ for $24 \mathrm{~h}$ prior to infection with $\mathrm{H} 101$ Ads at a multiplicity of infection (MOI) of 100, and in the presence or absence of $0.3 \mu \mathrm{M}$ TSA. The cells and the supernatants were harvested 24, 48 and $72 \mathrm{~h}$ following infection, freeze-thawed 3 times and serially diluted. HEK293 cells (Shanghai Institute of Biochemistry and Cell Biology, Chinese Academy of Science, Shanghai, China) were seeded at a density of $1 \times 10^{5}(100 \mu \mathrm{l})$ cells/well with 2\% DMEM in 96-well microtiter plates. Each sample (cells and supernatants) that was diluted serially 10 times with $2 \%$ DMEM was added to 96 -well microtiter plates at $37^{\circ} \mathrm{C}$ for 10 days. Each titer was repeated 10 times. The same volume of $2 \%$ DMEM was added as a control. Viral titers were calculated by infecting serially diluted virus particles in HEK293 and determined using the limiting dilution method (4) (determination of the $50 \%$ infective dose in tissue culture using HEK293 cells).

Co-treatment of ECl cells with TSA and H101 oncolytic Ads. EC1 cells were seeded at a density of $5 \times 10^{5}$ cells/well at $37^{\circ} \mathrm{C}$ in 96-well microtiter plates. Following culture at $37^{\circ} \mathrm{C}$ for $24 \mathrm{~h}$, cells were incubated with H101 Ads at an MOI of 100 in the presence or absence of $0.3 \mu \mathrm{M}$ TSA for 24,48 and $72 \mathrm{~h}$. Cell viability was evaluated using CCK-8. A total of $10 \mu \mathrm{l}$ of the CCK-8 solution was added to each well and incubated at $37^{\circ} \mathrm{C}$ for $2 \mathrm{~h}$. Absorbance was determined at a wavelength of $450 \mathrm{~nm}$ for each well using an enzyme-labeling instrument (Multiskan G0). All experiments were performed independently in triplicate.

Animal treatments. $\mathrm{Nu} / \mathrm{nu}$ athymic female mice, 4-6 weeks old and weighing 18-22 g, were obtained from Shanghai Laboratory Animal Co. Ltd. (Shanghai, China). All animals were housed in specific pathogen free laminar airflow boxes at a temperature of $25-26^{\circ} \mathrm{C}$, with a humidity of $50 \%$, and administered sterile food and water ad libitum. The mice were treated in accordance with the Guide for the Care and Use of Laboratory Animals of Henan Province, China, and experimental procedures were approved by the Medical Ethics Committee of Zhengzhou University (Zhengzhou, China). To obtain xenograft tumors, a $4 \times 10^{6} \mathrm{EC} 1$ cell resuspension $(200 \mu \mathrm{l})$ was injected subcutaneously into the dorsal right flank of the athymic mice. The animals were monitored for tumor grow th every other day. Upon reaching the required mean tumor volume of $\sim 100 \mathrm{~mm}^{3}$ (volume = length $\mathrm{x}$ width ${ }^{2} \mathrm{x} 0.5$ ), a total of 24 mice were randomly assigned to the following 4 groups (6 mice per group): The TSA alone group, the H101 alone group, the TSA and H101 combination treatment group, and the control group. The treatment protocol comprised of TSA $(0.3 \mu \mathrm{mol} / 1,200 \mu 1 \mathrm{TSA})$ administered as intratumoral injections 3 days prior to H101 injection. The H101 treatment protocol comprised of $100 \mu \mathrm{l} \mathrm{H} 101\left(1 \times 10^{8}\right.$ plaque-forming units) administered as intratumoral injections on days $2,7,11$, 15 and 19. The control group received five injections of $100 \mu 1$ PBS on days 2, 7, 11, 15 and 19. Tumor size was measured every 7 days using Vernier calipers. The mice from each group were sacrificed by cervical dislocation on day 21 .

Immunohistochemical analysis. Tissue sections preserved in $2.5 \%$ glutaraldehyde-polyoxymethylene solution at room temperature for $24 \mathrm{~h}$, were dehydrated and embedded in 
paraffin following routine methods, and sectioned to $4-\mu \mathrm{m}$ thick. The sections were deparaffinized in xylene followed by treatment with a graded series of ethanol and distilled water, and thorough rinsing with PBS. Following microwave treatment in citrate buffer ( $\mathrm{pH}$ 6.0), the container was placed in boiled water for $20 \mathrm{~min}$. Endogenous peroxidase activity was blocked with $3 \%$ hydrogen peroxide in methanol at room temperature for $10 \mathrm{~min}$. The tissue samples were incubated with a rabbit anti-coxsackie and adenovirus receptor (CAR) monoclonal antibody (dilution, 1:200; catalog no. sc-50462; Santa Cruz Biotechnology, Inc., Dallas, TX, USA) overnight at $4^{\circ} \mathrm{C}$. Following washing three times with PBS, the tissue samples were incubated for $30 \mathrm{~min}$ with the goat anti-rabbit IgG-horseradish peroxidase secondary antibody (dilution, 1:2,000; catalog no. sc-2004; Santa Cruz Biotechnology, Inc.). Antibody binding was subsequently detected using $0.5 \%$ 3,3'-diaminobenzidine hydrochloride (DAB; Sigma-Aldrich; Merck Millipore) at room temperature without light for $3 \mathrm{~min}$. The sections were then washed three times with PBS, counterstained with hematoxylin for $15 \mathrm{sec}$ and dehydrated at room temperature. The images were analyzed by Image-Pro Plus 6.0 (Media Cybernetics, Inc., Rockville, MD, USA).

Western blot analysis. Tumor tissues from xenografts of the aforementioned mice were lysed in lysis buffer $(50 \mathrm{mM}$ Tris-HCl, pH 8.0, $150 \mathrm{mM} \mathrm{NaCl}, 1 \%$ Triton X-100, $100 \mu \mathrm{g} / \mathrm{ml}$ phenylmethylsulfonyl fluoride) for tissue homogenization. After $20 \mathrm{~min}$ on ice, the lysates were centrifuged at 20,430 x $g$ at $4^{\circ} \mathrm{C}$ for $10 \mathrm{~min}$. The supernatants were used as whole cell extracts. Cell lysates $(50 \mu \mathrm{g})$ were separated using $10 \%$ SDS-PAGE and transferred to polyvinylidene fluoride membranes. The membranes were incubated with $5 \%$ non-fat dried milk dissolved in Tris-buffered saline containing $0.1 \%$ Tween-20 for $1 \mathrm{~h}$ at room temperature. The membranes were then incubated with a rabbit CAR monoclonal antibody (dilution, 1:200; Santa Cruz Biotechnology, Inc.) at $4^{\circ} \mathrm{C}$ overnight. After washing three times with $0.1 \%$ TBS-T, the tissue samples were incubated with the aforementioned horseradish peroxidase-conjugated $\operatorname{IgG}$ secondary antibody for $2 \mathrm{~h}$ at room temperature. A Pierce ${ }^{\mathrm{TM}}$ enhanced chemiluminescence detection kit (Thermo Fisher Scientific, Inc.) was used to detect the target proteins. The bands were subjected to densitometry for quantitation using the Bio-Rad Quantity One ${ }^{\circledR}$ software (version 4.6.2; Bio-Rad Laboratories, Inc., Hercules, CA, USA).

Statistical analysis. Quantitative data were expressed as the mean \pm standard deviation. One-way analysis of variance was used to compare significant differences amongst the groups. Two-tailed Student's $t$-tests were used for comparisons between two groups. Data analyses were performed using SPSS 13.0 software for Windows (SPSS Inc., Chicago, IL, USA). P<0.05 was considered to indicate a statistically significant difference.

\section{Results}

Effect of TSA on the growth of ECl cells. TSA, an established class I and II HDACI, has been reported to exert numerous antitumor effects by inhibiting cell proliferation and inducing cell apoptosis (24). The present study aimed to examine the ability
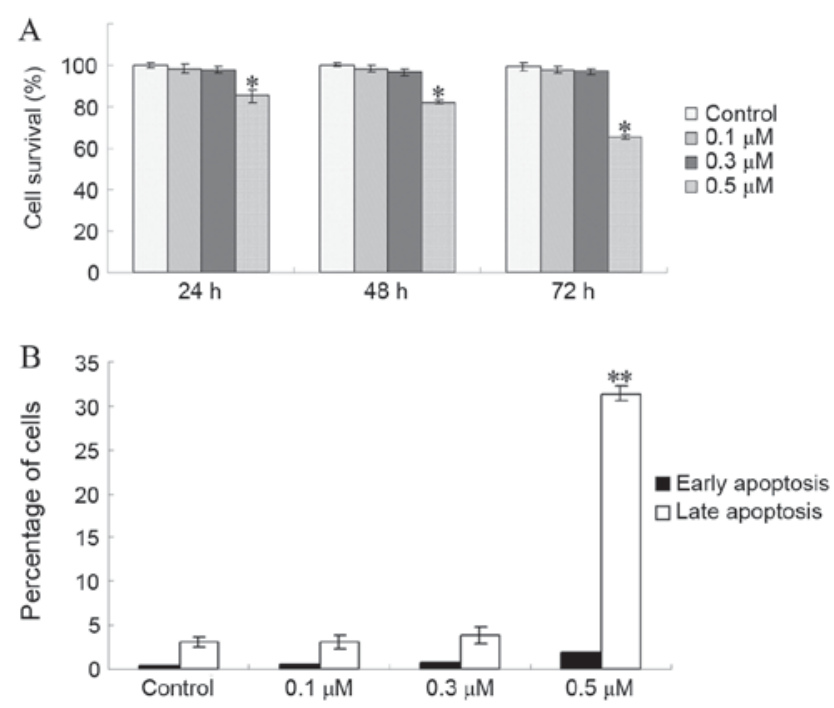

Figure 1. Effects of TSA treatment on the growth of EC1 cells. (A) The cell viability of EC1 cells treated with TSA at the indicated concentrations for 24 48 and $78 \mathrm{~h}$ was determined using a CCK-8 assay. (B) Effects of TSA on cell apoptosis in EC1 cells treated with TSA $(0.1,0.3$ and $0.5 \mu \mathrm{M})$ for $72 \mathrm{~h}$. EC1 cells were stained with Annexin V/PI and analyzed by flow cytometry. All data are presented as the mean \pm standard deviation of values from triplicate experiments. ${ }^{*} \mathrm{P}<0.05$ and ${ }^{* *} \mathrm{P}<0.01$, compared with vehicle treatment. TSA, trichostatin A.

of TSA to promote the antitumor effects of oncolytic H101, but not to affect cell viability. Therefore, EC1 cells were treated with various concentrations of TSA, and EC1 cell viability and apoptosis were evaluated. As presented in Fig. 1A, the viability of EC1 cells was not significantly inhibited by TSA at doses of 0.1 and $0.3 \mu \mathrm{M}$ after $72 \mathrm{~h}$ of treatment $(\mathrm{P}=0.542$ for $0.1 \mu \mathrm{M}$ vs. control; $\mathrm{P}=0.218$ for $0.3 \mu \mathrm{M}$ vs. control). However, the viability of EC1 cells was significantly inhibited at doses $>0.5 \mu \mathrm{M}(\mathrm{P}<0.001$; Fig. 1A). In addition, the proportion of EC1 cells in early apoptosis was not markedly increased at TSA doses $<0.3 \mu \mathrm{M}$ ( $\mathrm{P}=0.773$ for $0.1 \mu \mathrm{M}$ vs. control; $\mathrm{P}=0.350$ for $0.3 \mu \mathrm{M}$ vs. control; Fig. 1B). These results indicated that doses of $\leq 0.3 \mu \mathrm{M}$ TSA did not significantly alter EC1 cell viability.

Increased $H 101$ replication and cell cytotoxicity is mediated by TSA and H101 in combination. To examine whether TSA is able to impact $\mathrm{H} 101$ replication, end point dilution titrations were performed on HEK293 cells. Following treatment with $0.3 \mu \mathrm{M}$ TSA for 24, 48 and $72 \mathrm{~h}$, viral titers increased 55.82-fold, 238.84-fold and 527.46-fold in EC1 cells, respectively (Fig. 2A). H101 replication was significantly increased in EC1 cells treated with TSA, compared with the untreated control cells $(\mathrm{P}=0.002$ for TSA 24 h vs. control; $\mathrm{P}<0.001$ for TSA $48 \mathrm{~h}$ vs. control; $\mathrm{P}<0.001$ for TSA $72 \mathrm{~h}$ vs. control). Subsequently, the antitumor effects of TSA on H101 in EC1 cells were examined. A CCK- 8 assay was used to measure the EC1 cell survival rate at 12, 24, 48, 72 and $96 \mathrm{~h}$ following treatment. As compared with the H101 monotherapy group, the cell survival rate in the TSA and H101 combination group exhibited a significant decrease at 24, 48 and $72 \mathrm{~h}(\mathrm{P}<0.001$; Fig. 2B).

Effect of TSA and H101 combination treatment on the ECI xenograft model. TSA and H101 in combination enhanced 

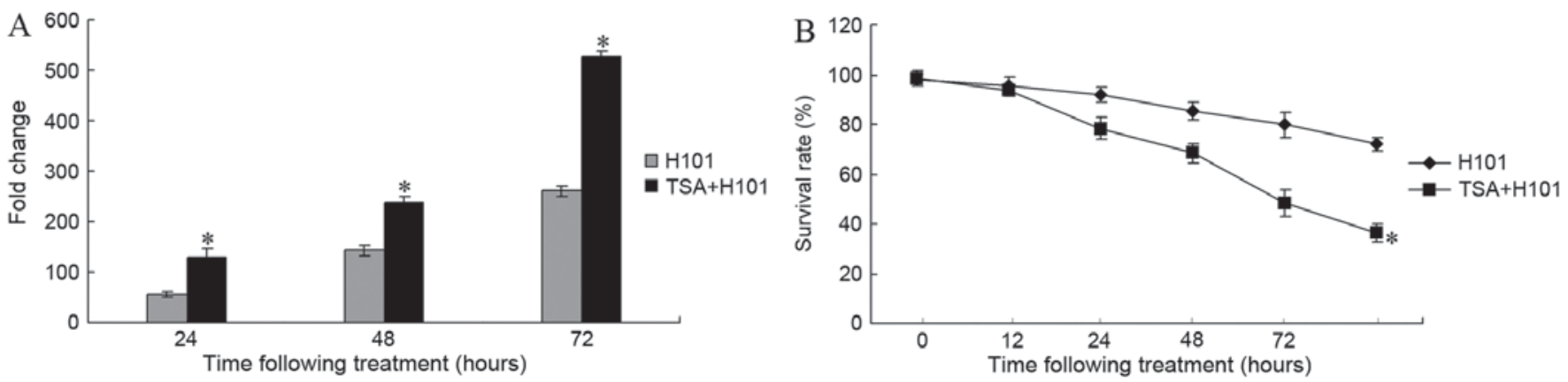

Figure 2. Increased replication of the H101 virus and cell cytotoxicity mediated by TSA and H101 in combination, as compared with H101 treatment alone. (A) Replication of H101 virions induced by TSA. EC1 cells were treated with $0.3 \mu \mathrm{M}$ TSA or vehicle for 24,48 and $72 \mathrm{~h}$ and subsequently infected with H101 Ads at an MOI of 100. The viral titers of H101 were evaluated using the limiting dilution method. (B) Cell viability assay following treatment with TSA and H101 combination. Cell viability was measured using CCK- 8 at 24, 48, 72 and $96 \mathrm{~h}$ following treatment with TSA $(0.3 \mu \mathrm{M})$ in combination with H101 infection $(\mathrm{MOI}=100)$. All data are presented as the mean $\pm \mathrm{SD}$ of three independent experiments. ${ }^{\prime} \mathrm{P}<0.05$, compared with H101 treatment alone. TSA, trichostatin A; Ads, adenovirus; MOI, multiplicity of infection; SD, standard deviation.

tumor cell cytotoxicity in vitro. Therefore, in order to examine whether this treatment is able to inhibit EC1 tumor growth in vivo, tumor bearing mice were divided into various treatment groups as described in material and methods. As compared with the PBS control group, mice treated with TSA alone did not exhibit tumor regression and there was no significant difference in the tumor volume at the end of treatment $(\mathrm{P}=0.148)$. In the TSA and H101 combination treatment group, a significant decrease in tumor volume $\left(286.53 \pm 28.99 \mathrm{~mm}^{3}\right)$ was observed, as compared with the untreated controls $\left(1459.79 \pm 76.81 \mathrm{~mm}^{3}\right)$ $(\mathrm{P}<0.001)$. Furthermore, a significant decrease in the tumor volume was detected in the TSA and H101 combination group, as compared with the two treatments administered individually (both $\mathrm{P}<0.001$ ). The results indicate that TSA and H101 in combination produce an enhanced antitumor effect, compared with the two treatments administered individually (Fig. 3A). In addition, marked variations were identified in the degree of inflammation and necrosis observed in the tumor specimens in the TSA and H101 combination group, compared with the groups in which TSA and H101 were administered individually (both $\mathrm{P}<0.001$; Fig. $3 \mathrm{~A}$ and $\mathrm{B}$ ).

TSA alone, or combined with H101, upregulates the expression of CAR in an ECl cell-xenograft model. To investigate whether the enhanced antitumor effects of TSA and H101 combined in vivo were achieved via the upregulation of CAR, the expression levels of CAR in the xenograft tumor tissues were detected using immunohistochemistry. An increase in the expression levels of CAR in xenograft tumors was observed in the TSA group and in the TSA and H101 combination group, as compared with the control group and the H101 group (Fig. 4A). Western blot analysis also demonstrated that the CAR protein levels were increased in the TSA group and the TSA in combination with $\mathrm{H} 101$ group (both $\mathrm{P}<0.001$; Fig. 4B and C). These results indicated that TSA intratumoral injections may result in increased levels of CAR expression in xenograft tumors in mice.

\section{Discussion}

The tumor suppressor gene tumor protein p53 is considered an attractive target for cancer gene therapy (28-30). The human p53 gene is known as the 'guardian of the genome' for its roles in regulating the cell cycle, apoptosis and cellular senescence, as well as inducing a variety of activities to maintain genomic stability $(31,32)$. Mutant $\mathrm{p} 53$ has been demonstrated to be overexpressed in the tumor tissues of patients with ESCC and its expression levels are correlated with tumor progression (33). Therefore, Ads-mediated p53 cancer gene therapy constitutes a promising treatment approach for patients with ESCC (34). H101 is a recombinant human type 5 Ads with a total deletion of the E1B $55 \mathrm{~K}$ gene, which is able to proliferate effectively in p53 mutant cells, but not in p53 wild-type cells (35). However, H101 has limited potential for the eradication of tumors when used as a monotherapy due to its low infection efficiency (10). Therefore, a high degree of viral transduction within the tumor is key to the success of gene therapy approaches. H101 is often used in combination with traditional modalities, including chemotherapy (36). In the present study, the antitumor efficacy of H101 in combination with the HDACI TSA was evaluated.

The H101 OV enters malignant cells through a receptormediated endocytosis mechanism (37). CAR is necessary for adenoviral entry into the cell; however, this receptor is frequently downregulated in malignant cells, rendering them less vulnerable to viral attack (38). It has been reported that HDACIs are able to enhance transgene expression, making them suitable for use in conjunction with adenoviral vector-based therapies due to their ability to increase CAR expression levels (39).

Although TSA was one of the first HDACIs to be identified, its suboptimal in vivo stability limits its use as a widely administered cancer treatment (40). Furthermore, TSA is more effective at promoting vaccinia virus spread in vitro, compared with TSA derivatives, by increasing the expression levels of CAR in malignant cells, and leading to more efficient cell killing compared with other HDACIs, including vorinistat (40). In the present study, TSA was selected to enhance the antitumor efficacy of H101 with the purpose of evaluating the ability of TSA to enhance H101 viral oncolysis without altering cell viability. Following the treatment of EC1 cells with various concentrations of TSA and the subsequent evaluation of cell viability, the data indicated that a dose of $0.3 \mu \mathrm{M}$ TSA delivered to EC1 cells was well-tolerated and did not induce apoptosis. However, the treatment of EC1 cells with 

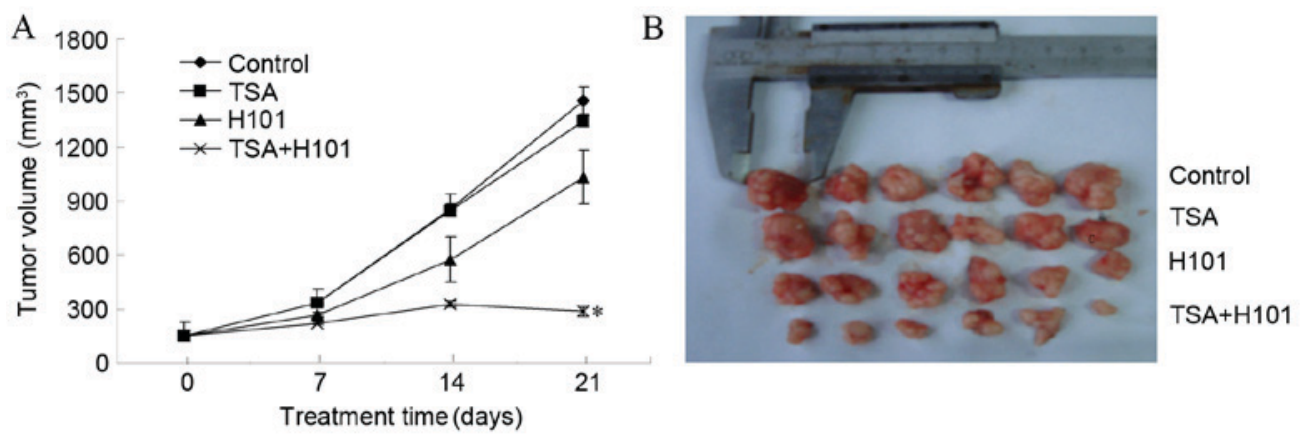

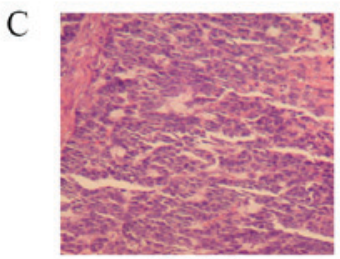

Control

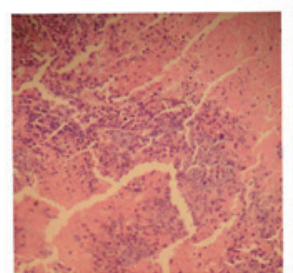

H101

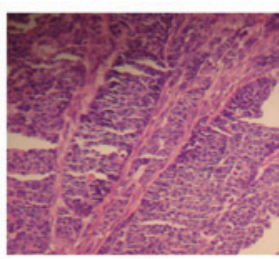

TSA

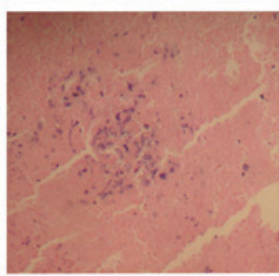

H101+TSA

A

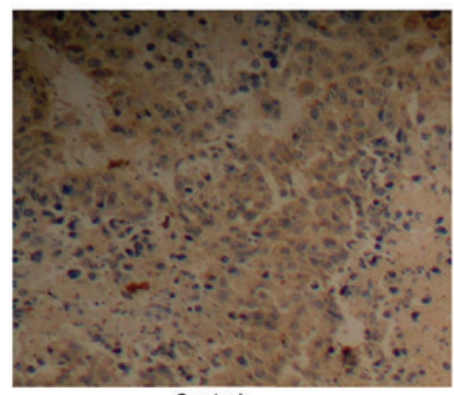

Control
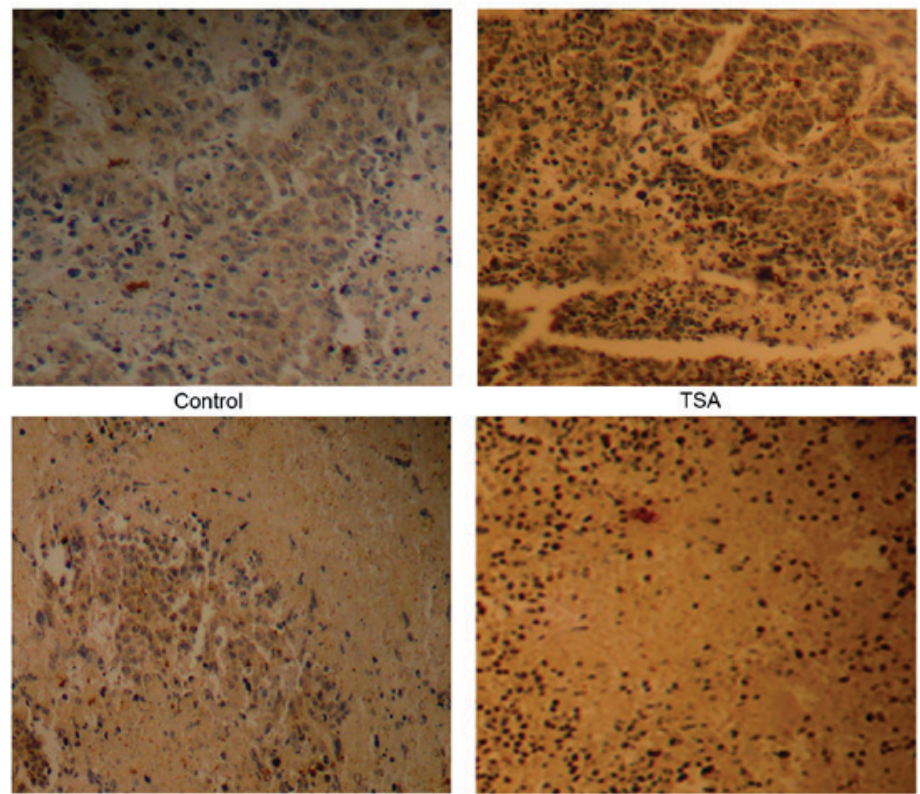

H101
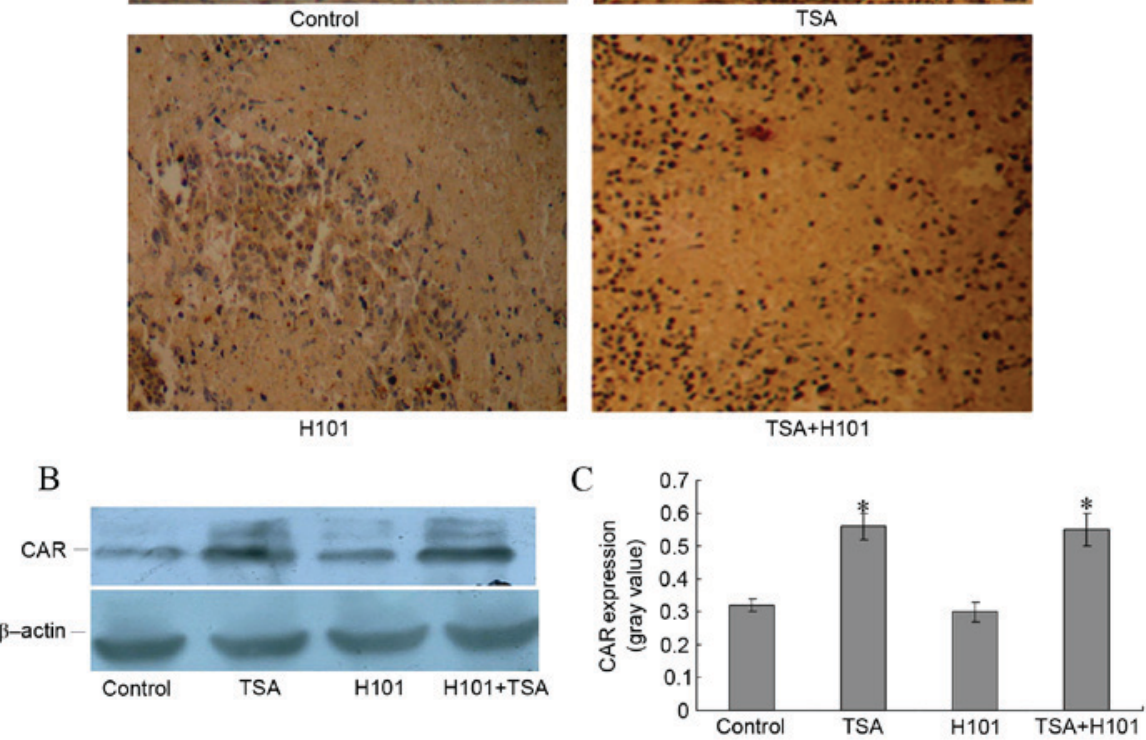

Figure 4. Expression of CAR in EC1 mouse xenograft tissue upon various forms of treatment. (A) Immunohistochemical evaluation of CAR expression in EC1 xenograft tissue treated with control (PBS), TSA, H101 and TSA+H101 (magnification, x200). (B) Expression levels of CAR in EC1 xenograft tissue as investigated by western blot analysis. Each blot is representative of three independent experiments. (C) Gray values of CAR expression are presented as the mean \pm standard deviation. ${ }^{*} \mathrm{P}<0.05$, compared with the with control group. CAR, coxsackie and adenovirus receptor; TSA, trichostatin A; SD, standard deviation. 
$0.3 \mu \mathrm{M}$ TSA increased $\mathrm{H} 101$ replication and cell cytotoxicity. These results indicate that TSA is able to enhance the antitumor efficacy of H101 in vitro.

Previous studies have indicated that a number of factors may lead to a discrepancy between the efficacy data obtained from cell culture in vitro, and the in vivo data $(15,41)$. In cell culture monolayer, all infectable cells are easily accessed by viruses. By contrast, aspects of the tumor architecture, including fibrotic septa and necrotic areas in tumor tissue, prevent the virus from spreading in vivo (9). This leads to an inconsistency between the efficacy obtained from cell culture experiments in vitro and in clinical trials. Therefore, their efficacy of viral oncolysis need to be improved (42-45). The present study examined whether the enhanced in vitro tumor cytotoxicity, mediated by TSA and H101 in combination, was also exhibited during EC1 cell tumor growth in vivo. In comparison with the TSA group and the H101 group, a significant decrease in tumor volume in the TSA and H101 combination group was observed. This result indicates that the use of TSA and H101 in combination produced an enhanced antitumor effect in vivo.

Subsequently, the mechanisms underlying the ability of TSA to enhance the antitumor effects of H101 were investigated. Lower expression levels of CAR protein have been reported in ESCC cells (46). In addition, Wei Lu et al proved that an intratumoral injection of chemotherapy in combination with $\mathrm{H} 101$ exhibits better antitumor activity to refractory malignant tumors than H101 alone (46). It has become apparent that a major determinant of Ads-mediated gene transfer efficacy is the expression of its primary receptor, CAR, on target cells (47). In order to infect tumor cells efficiently, H101 requires CAR for attachment and $\alpha_{v}$ integrin for internalization (48). In the present study, the expression levels of CAR in the mouse xenograft tumor tissue were increased in the TSA group, and in the TSA and H101 combination group. These results suggest that TSA intratumoral injections may enhance the H101 antitumor effect by increasing CAR expression levels in vivo.

In conclusion, the HDACI TSA is able to enhance the antitumor effect of the OV H101 on ESCC cells in vitro and in vivo. HDACIs combined with OVs may therefore be able to overcome the obstacle of the low infection efficiency of H101 when used as monotherapy.

\section{Acknowledgements}

This study was supported by the National Natural Science Foundation of China (grant no. 81372269), the Science Foundation of Henan Education Department (grant no. 13A310622) and the Key project on Science and Technology provided by Henan Province, China (grant nos. 152102410067, 162102310142 and 201403035).

\section{References}

1. Fujiwara Y, Yoshikawa R, Kamikonya N, Nakayama T, Kitani K, Tsujie M, Yukawa M, Inoue M and Yamamura T: Trimodality therapy of esophagectomy plus neoadjuvant chemoradiotherapy improves the survival of clinical stage II/III esophageal squamous cell carcinoma patients. Oncol Rep 28: 446-452, 2012.
2. Jemal A, Center MM, DeSantis C and Ward EM: Global patterns of cancer incidence and mortality rates and trends. Cancer Epidemiol Biomarkers Prev 19: 1893-1907, 2010.

3. Bonavina L, Incarbone R, Saino G, Clesi P and Peracchia A: Clinical outcome and survival after esophagectomy for carcinoma in elderly patients. Dis Esophagus 16: 90-93, 2003.

4. Wang Y, Thorne S, Hannock J, Francis J, Au T, Reid T, Lemoine N Kirn D and Halldén G: A novel assay to assess primary human cancer infectibility by replication-selective oncolytic adenoviruses. Clin Cancer Res 11: 351-360, 2005.

5. Zhu H, Huo X, Chen L, Wang $\mathrm{H}$ and $\mathrm{Yu} \mathrm{H}$ : Clinical experience with radio-, chemo- and hyperthermotherapy combined trimodality on locally advanced esophageal cancer. Mol Clin Oncol 1: 1009-1012, 2013.

6. Fujiwara Y, Yoshikawa R, Kamikonya N, Nakayama T, Kitani K, Tsujie M, Yukawa M, Hara J, Yamamura T and Inoue M: Neoadjuvant chemoradiotherapy followed by esophagectomy vs. surgery alone in the treatment of resectable esophageal squamous cell carcinoma. Mol Clin Oncol 1: 773-779, 2013.

7. Minsky BD, Pajak TF, Ginsberg RJ, Pisansky TM, Martenson J, Komaki R, Okawara G, Rosenthal SA and Kelsen DP: INT 0123 (Radiation Therapy Oncology Group 94-05) phase III trial of combined-modality therapy for esophageal cancer: High-dose versus standard-dose radiation therapy. J Clin Oncol 20: 1167-1174, 2002.

8. Garber K: China approves world's first oncolytic virus therapy for cancer treatment. J Natl Cancer Inst 98: 298-300, 2006.

9. Lu W, Zheng S, Li XF, Huang JJ, Zheng X and Li Z: Intra-tumor injection of $\mathrm{H} 101$, a recombinant adenovirus, in combination with chemotherapy in patients with advanced cancers: A pilot phase II clinical trial. World J Gastroenterol 10: 3634-3638, 2004.

10. Toth K and Wold WS: Increasing the efficacy of oncolytic adenovirus vectors. Viruses 2: 1844-1866, 2010.

11. Thorne SH, Hermiston T and Kirn D: Oncolytic virotherapy: Approaches to tumor targeting and enhancing antitumor effects. Semin Oncol 32: 537-548, 2005.

12. Lichtenstein DL and Wold WS: Experimental infections of humans with wild-type adenoviruses and with replication-competent adenovirus vectors: Replication, safety and, transmission. Cancer Gene Ther 11: 819-829, 2004.

13. Nettelbeck DM, Jérôme V and Müller R: Gene therapy: Designer promoters for tumour targeting. Trends Genet 16: 174-181, 2000.

14. Tysome JR, Lemoine NR and Wang Y: Combination of anti-angiogenic therapy and virotherapy: Arming oncolytic viruses with anti-angiogenic genes. Curr Opin Mol Ther 11: 664-669, 2009.

15. Nguyen TL, Wilson MG and Hiscott J: Oncolytic viruses and histone deacetylase inhibitors-a multi-pronged strategy to target tumor cells. Cytokine Growth Factor Rev 21: 153-159, 2010.

16. Reid TR, Freeman S, Post L, McCormick F and Sze DY: Effects of Onyx-015 among metastatic colorectal cancer patients that have failed prior treatment with 5-FU/leucovorin. Cancer Gene Ther 12: 673-681, 2005.

17. Kumar S, Gao L, Yeagy B and Reid T: Virus combinations and chemotherapy for the treatment of human cancers. Curr Opin Mol Ther 10: 371-379, 2008.

18. Bhattacharyya M, Francis J, Eddouadi A, Lemoine NR and Halldén G: An oncolytic adenovirus defective in pRb-binding (d1922-947) can efficiently eliminate pancreatic cancer cells and tumors in vivo in combination with 5-FU or gemcitabine. Cancer Gene Ther 18: 734-743, 2011.

19. Barbetti V, Gozzini A, Cheloni G, Marzi I, Fabiani E, Santini V, Dello Sbarba P and Rovida E: Time- and residue-specific differences in histone acetylation induced by VPA and SAHA in AML1/ETO-positive leukemia cells. Epigenetics 8: 210-219, 2013.

20. Ellis L, Atadja PW and Johnstone RW: Epigenetics in cancer: Targeting chromatin modifications. Mol Cancer Ther 8: $1409-1420,2009$.

21. Meng F, Sun G, Zhong M, Yu Y and Brewer MA: Inhibition of DNA methyltransferases, histone deacetylases and lysine-specific demethylase-1 suppresses the tumorigenicity of the ovarian cancer ascites cell line SKOV3. Int J Oncol 43: 495-502, 2013.

22. Wilson PM, Labonte MJ, Martin SC, Kuwahara ST, El-Khoueiry A, Lenz HJ and Ladner RD: Sustained inhibition of deacetylases is required for the antitumor activity of the histone deactylase inhibitors panobinostat and vorinostat in models of colorectal cancer. Invest New Drugs 31: 845-857, 2013.

23. Minucci S and Pelicci PG: Histone deacetylase inhibitors and the promise of epigenetic (and more) treatments for cancer. Nat Rev Cancer 6: 38-51, 2006. 
24. Stankov MV, El Khatib M, Kumar Thakur B, Heitmann K, Panayotova-Dimitrova D, Schoening J, Bourquin JP, Schweitzer N, Leverkus M, Welte K, et al: Histone deacetylase inhibitors induce apoptosis in myeloid leukemia by suppressing autophagy. Leukemia 28: 577-588, 2014.

25. Ye RR, Ke ZF, Tan CP, He L, Ji LN and Mao ZW: Histonedeacetylase-targeted fluorescent ruthenium(II) polypyridyl complexes as potent anticancer agents. Chemistry 19: 10160-10169, 2013.

26. Chen X, Xiao W, Chen W, Luo L, Ye S and Liu Y: The epigenetic modifier trichostatin A, a histone deacetylase inhibitor, suppresses proliferation and epithelial-mesenchymal transition of lens epithelial cells. Cell Death Dis 4: e884, 2013.

27. Yen CC, Chen YJ, Chen JT, Hsia JY, Chen PM, Liu JH, Fan FS, Chiou TJ, Wang WS and Lin CH: Comparative genomic hybridization of esophageal squamous cell carcinoma: Correlations between chromosomal aberrations and disease progression/ prognosis. Cancer 92: 2769-2777, 2001.

28. Li LX, Zhang YL, Zhou L, Ke ML, Chen JM, Fu X, Ye CL, Wu JX, Liu RY and Huang W: Antitumor efficacy of a recombinant adenovirus encoding endostatin combined with an E1B55KD-deficient adenovirus in gastric cancer cells. J Transl Med 11: 257, 2013

29. Huang H, Xiao T, He L, Ji H and Liu XY: Interferon- $\beta$-armed oncolytic adenovirus induces both apoptosis and necroptosis in cancer cells. Acta Biochim Biophys Sin (Shanghai) 44: 737-745, 2012.

30. Essmann F and Schulze-Osthoff K: Translational approaches targeting the p53 pathway for anti-cancer therapy. Br J Pharmacol 165: 328-344, 2012.

31. Krell J, Frampton AE, Colombo T, Gall TM, De Giorgio A, Harding V, Stebbing J and Castellano L: The p53 miRNA interactome and its potential role in the cancer clinic. Epigenomics 5 : 417-428, 2013

32. Lee JY, Kim HJ, Yoon NA, Lee WH, Min YJ, Ko BK, Lee BJ, Lee A, Cha HJ, Cho WJ and Park JW: Tumor suppressor p53 plays a key role in induction of both tristetraprolin and let-7 in human cancer cells. Nucleic Acids Res 41: 5614-5625, 2013.

33. Huang K, Chen L, Zhang J, Wu Z, Lan L, Wang L, Lu B and Liu Y: Elevated p53 expression levels correlate with tumor progression and poor prognosis in patients exhibiting esophageal squamous cell carcinoma. Oncol Lett 8: 1441-1446, 2014.

34. D'Assoro AB, Leontovich A, Amato A, Ayers-Ringler JR, Quatraro C, Hafner K, Jenkins RB, Libra M, Ingle J, Stivala F, et al: Abrogation of p53 function leads to metastatic transcriptome networks that typify tumor progression in human breast cancer xenografts. Int J Oncol 37: 1167-1176, 2010.

35. Song X, Zhou Y, Jia R, Xu X, Wang H, Hu J, Ge S and Fan X: Inhibition of retinoblastoma in vitro and in vivo with conditionally replicating oncolytic adenovirus H101. Invest Ophthalmol Vis Sci 51: 2626-2635, 2010
36. Alvarez-Breckenridge C,Kaur B and Chiocca EA: Pharmacologic and chemical adjuvants in tumor virotherapy. Chem Rev 109: 3125-3140, 2009.

37. Walters RW, Freimuth P, Moninger TO, Ganske I, Zabner J and Welsh MJ: Adenovirus fiber disrupts CAR-mediated intercellular adhesion allowing virus escape. Cell 110: 789-799, 2002.

38. Kothari V, Joshi G, Nama S, Somasundaram K and Mulherkar R: HDAC inhibitor valproic acid enhances tumor cell kill in adenovirus-HSVtk mediated suicide gene therapy in HNSCC xenograft mouse model. Int J Cancer 126: 733-742, 2010.

39. Auer D, Reimer D, Porto V, Fleischer M, Roessler J, Wiedemair A, Marth C, Müller-Holzner E, Daxenbichler G and Zeimet AG: Expression of coxsackie-adenovirus receptor is related to estrogen sensitivity in breast cancer. Breast Cancer Res Treat 116: 103-111, 2009.

40. MacTavish H, Diallo JS, Huang B, Stanford M, Le Boeuf F, De Silva N, Cox J, Simmons JG, Guimond T, Falls T, et al: Enhancement of vaccinia virus based oncolysis with histone deacetylase inhibitors. PLoS One 5: e14462, 2010.

41. Sauthoff H, Hu J, Maca C, Goldman M, Heitner S, Yee H, Pipiya T, Rom WN and Hay JG: Intratumoral spread of wild-type adenovirus is limited after local injection of human xenograft tumors: Virus persists and spreads systemically at late time points. Hum Gene Ther 14: 425-433, 2003.

42. Eikenes L, Bruland $\varnothing S$, Brekken $C$ and Davies Cde L: Collagenase increases the transcapillary pressure gradient and improves the uptake and distribution of monoclonal antibodies in human osteosarcoma xenografts. Cancer Res 64: 4768-4773, 2004.

43. Ferreira TB, Ferreira AL, Carrondo MJ and Alves PM: Two different serum-free media and osmolality effect upon human 293 cell growth and adenovirus production. Biotechnol Lett 27: $1809-1813,2005$

44. Henry O, Dormond E, Perrier M and Kamen A: Insights into adenoviral vector production kinetics in acoustic filter-based perfusion cultures. Biotechnol Bioeng 86: 765-774, 2004.

45. Jardon $\mathrm{M}$ and Garnier $\mathrm{A}: \mathrm{PH}, \mathrm{pCO} 2$, and temperature effect on R-adenovirus production. Biotechnol Prog 19: 202-208, 2003.

46. Ma J, Zhao J, Lu J, Jiang Y, Yang H, Li P, Zhao M, Liu K and Dong Z: Coxsackievirus and adenovirus receptor promotes antitumor activity of oncolytic adenovirus H101 in esophageal cancer. Int J Mol Med 30: 1403-1409, 2012.

47. Chen G, Wang BB, Li FJ, Liu DY, Zhou JF, Lu YP and Ma D: Enhancive effect of histone deacetylase inhibitor trichostatin a on transfection efficiency of adenovirus in ovarian carcinoma cell line A2780. Ai Zheng 24: 1196-1200, 2005 (In Chinese).

48. Pandha HS, Stockwin LH, Eaton J, Clarke IA, Dalgleish AG, Todryk SM and Blair GE: Coxsackie B and adenovirus receptor, integrin and major histocompatibility complex class I expression in human prostate cancer cell lines: Implications for gene therapy strategies. Prostate Cancer Prostatic Dis 6: 6-11, 2003. 